\title{
Phytoecological and phytoedaphological characterization of steppe plant communities in the south of Tlemcen (western Algeria)
}

\author{
Bahae-Ddine Ghezlaoui ${ }^{*}$, Noury Benabadji, Nedjwa Benabadji \\ Department of Biology, Faculty of Natural Sciences and Life Sciences and Earth and the Universe, Pôle la Rocade No. 2, University \\ of Tlemcen, Algeria; ${ }^{*}$ Corresponding Author: ghezlaouibahae@gmail.com
}

Received 23 September 2013; revised 23 October 2013; accepted 1 November 2013

Copyright (C) 2013 Bahae-Ddine Ghezlaoui et al. This is an open access article distributed under the Creative Commons Attribution License, which permits unrestricted use, distribution, and reproduction in any medium, provided the original work is properly cited.

\begin{abstract}
In Algeria, the steppe areas of southern Sebdou between Tlemcen, El-Aricha and Mecheria are the scene of an adverse and continuous ecological imbalance often caused by the strong support of human pressure in these ecosystems. In arid and semi-arid regions, salinity remains a constraint for the development of plants. This study focuses on the realization of floristic surveys, where attention was paid to areas occupied by the dominant perennial species (Tamarix gallica L.). A correspondence analysis by Minitab 15 software has allowed us to individualize the groups of species attracted by some parameters (edaphic, nitrates, humidity), and ecological gradients appear to affect the distribution of these taxa. The study of plant diversity shows the dominance of biological type of therophytes (41\%) and morphological type of the Chenopodiaceaes with (25\%). For geographical types, the strict Mediterranean and circum-Mediterranean element predominates.
\end{abstract}

Keywords: Halophytes; Tamaricacées; Salinity; Human Impact; Algeria

\section{INTRODUCTION}

The flora of the arid, especially of high plains Algerian steppe is discontinuous. Plants use mainly the locations where water is a little more accessible than elsewhere. The vegetation of the steppe regions is relatively homogeneous and Mediterranean penetrations are common [1,2]. Endemism is high in these vast spaces [3]. A human action such as the action of man and his herd is a major factor that catalyzes the degradation of plant cover in these ecosystems.

The apparent homogeneity of the vegetation in xeric and halophytes hides considerable heterogeneity that is related to the diversity of microclimates, topography and varying degrees of human pressure [4]. Algerian steppe is an expanse of 20 million hectares covered with low and sparse vegetation [5].

The overgrazing and long dry periods are among the factors that have contributed to increasing the fragility of these ecosystems and reducing their ability to regenerate, namely a decrease in their potential production [6]. The floristic analysis of different plant communities and their biological characteristics and chronologic could allow us to evaluate the critical value necessary for conservation management.

The objective of this work attaches great importance to the spatial distribution of plant taxa that occupy these places. This distribution follows a very irregular distribution of different plant species according to some environmental variations including climate, soil and human impact. This study highlights the influence of these parameters on the vector shown in factorial designs.

\section{MATERIALS AND METHODS}

\subsection{Location and Choice of Stations}

The region, as shown in Figure 1, is located in the western part of western Algeria. It is part of an area called "High Plains". The north side opposes a clear way for its richness and variety of its landscapes to aridity and the relative monotony of the vast plains that stretch to the South.

It is close to Dayet El Ferd, bordered by mountains to the northwest by the hills of Sidi Djilali (Jebel Tenouchfi, $1840 \mathrm{~m})$. It is bordered in the southwest by El-Abed Mountains $(1450 \mathrm{~m})$ and south-east by the mountains of El Gor (Djebel El-Hariga, $1600 \mathrm{~m}$ ). 


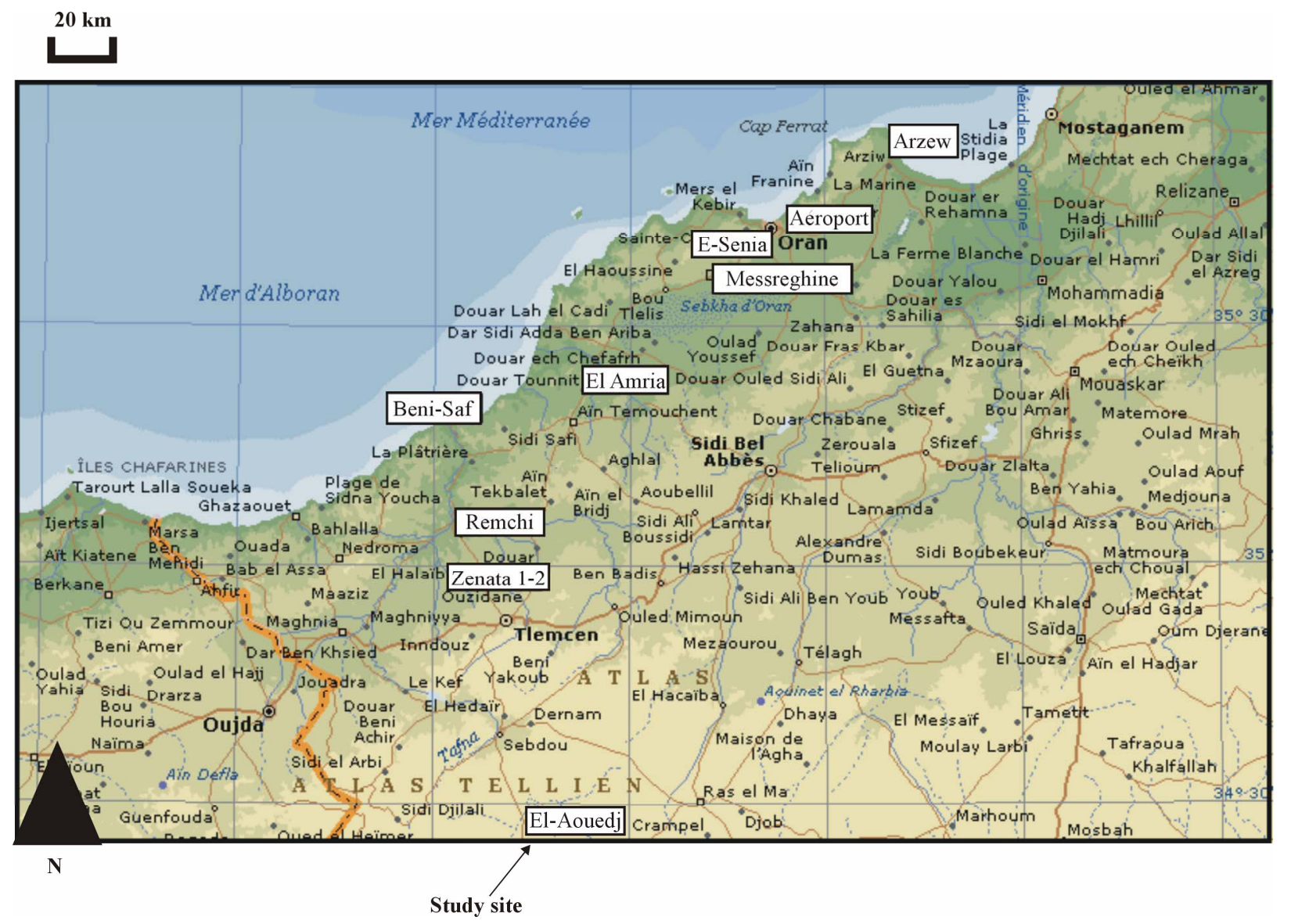

Figure 1. Location of study site.

The area is crossed by the National Road No. 22 connecting the cities of South Tlemcen (Sebdou, El-Aricha, Méchéria and Bechar). It lies to the north with a latitude of $34^{\circ} 29^{\prime}$ north and longitude $1^{\circ} 16^{\prime}$ West. It is a central part of the steppe zone of Tlemcen. The occupied area is about 73,700 ha.

\subsection{Climate Summary}

We took into account recent rainfall and temperatures, which are spread over almost fourteen years (1998-2012), taken at a weather station near El Aricha (Table 1).

This synthesis was based on a number of parameters such as climate regimes seasonal rainfall, the drought index, extreme temperatures, minimum values, and finally $\mathrm{Q}_{2}$ of Emberger. A positioning on pluviothermic climagramme of Emberger was made to clarify the bioclimatic zone.

\subsection{Soil Variables}

Along a transect, we conducted soil samples corresponding to the horizon searched by rooting foster taxa $[7,8]$. The locations of these samples to the total number of six were selected in floristically homogeneous areas, representative of the station studied. The samples with a shovel were brought to the laboratory in bags to carry out their analysis. Using a sieve of $2 \mathrm{~mm}$ in diameter, we recovered useful for the realization of physicochemical analyzes fine soil.

The measured parameters were: particle size, $\mathrm{pH}$, salinity and organic matter, the rate of limestone and Munsell color (Table 2).

\subsection{Floristic Diversity}

In the arid conditions of the study area, the vegetation remains highly sensitive to climatic and mechanical influences, such as grazing or clearing [9].

In these areas, the kind Tamarix is among the taxa that play an important role in soil conservation against different physical erosion. Hardiness acquired resistance to drought, gives it a special interest in the floristic composition of the study area. The paths of these regions are also characterized by unfavorable conditions, mainly related to abiotic stresses (drought, salinity).

As a result of their location-related schemes aridity and well-defined salinity, halophytes are divided into groups arranged in zones around continental saline depressions or along the seashore [10]. 
Table 1. Average monthly rainfall and temperatures in the station of El-Aricha during the period 1998-2012.

\begin{tabular}{ccccccccccccccccc}
\hline Station & Months & J. & F. & M. & A & Ma & Ju & Jul. & Au. & S. & O. & N. & D. & $\begin{array}{c}\text { Annual rainfall } \\
(\mathrm{mm})\end{array}$ \\
\hline El-Aricha & $\begin{array}{c}\text { Annual rainfall } \\
(\mathrm{mm}) \\
\begin{array}{c}\text { Temperature } \\
\left({ }^{\circ} \mathrm{C}\right)\end{array}\end{array}$ & 21.3 & 16.4 & 24.4 & 21.2 & 19.6 & 5.1 & 3.1 & 7.8 & 15.4 & 19.9 & 21.5 & 12.0 & 188.1 \\
& 6.2 & 9.5 & 9.8 & 17.4 & 22.2 & 27.4 & 27 & 20.7 & 14.7 & 8.8 & 5.5 & $\begin{array}{c}5\left({ }^{\circ} \mathrm{C}\right) \\
-2.2\end{array}$ & $\begin{array}{c}\mathrm{M}\left({ }^{\circ} \mathrm{C}\right) \\
33.1\end{array}$ \\
\hline
\end{tabular}

Table 2. Results of physic-chemical analyzes of soil.

\begin{tabular}{|c|c|c|c|c|c|c|c|c|c|c|c|}
\hline \multirow{2}{*}{ Station } & \multirow{2}{*}{$\begin{array}{c}\text { Sample. } \\
\text { No }\end{array}$} & \multicolumn{4}{|c|}{ Soil texture (\%) } & \multirow{2}{*}{$\mathrm{pH}$} & \multirow{2}{*}{$\begin{array}{c}\mathrm{CaCO}_{3} \\
\%\end{array}$} & \multirow{2}{*}{$\begin{array}{c}\text { O.M } \\
\%\end{array}$} & \multirow{2}{*}{$\mathrm{C}\left(\%_{0}\right)$} & \multirow{2}{*}{$\begin{array}{c}\text { E.C } \\
\mathrm{mS} / \mathrm{cm}\end{array}$} & \multirow{2}{*}{$\begin{array}{l}\text { Color } \\
\text { Munsell }\end{array}$} \\
\hline & & $\mathrm{A}$ & $\mathrm{L}$ & $\mathrm{S}$ & $\mathrm{T}$ & & & & & & \\
\hline \multirow{6}{*}{$\begin{array}{c}\text { Dayet } \\
\text { El-Ferd }\end{array}$} & 1 & 10 & 17 & 31 & S.1 & 8.9 & 21.8 & 1.7 & 10.2 & 1.2 & $5 Y$ Y $5 / 4$ \\
\hline & 2 & 14 & 15 & 32 & S.1 & 8.9 & 23.6 & 1.8 & 10.4 & 7.3 & 5 YR5/6 \\
\hline & 3 & 18 & 34 & 26 & L.s & 8.7 & 17.2 & 2.2 & 13.2 & 1.2 & $5 \mathrm{YR} 5 / 6$ \\
\hline & 4 & 23 & 40 & 23 & $\mathrm{~L}$ & 8.7 & 16.3 & 3.5 & 20.6 & 4.4 & 5 YR $6 / 6$ \\
\hline & 5 & 10 & 23 & 29 & S.1 & 8.8 & 19 & 1.9 & 11.5 & 13.6 & 5 YR5/6 \\
\hline & 6 & 12 & 39 & 24 & L.s & 8.6 & 14.5 & 1.9 & 11.1 & 14.5 & $5 Y R 4 / 8$ \\
\hline
\end{tabular}

A: Clay; L: Silt; S: Sand; S.I: Sandy loam; L.s: Loamy sand; T: Soil Texture; $\mathrm{CaCO}_{3}$ : Limestone; O.M: Organic mater; C: Organic carbon; E.C: Electrical conductivity.

The method used for sampling the vegetation was that of Braun-Blanquet (1951) and Guinochet (1973) called stigmatiste $[11,12]$.

The surface of the record must be at least equal to the minimum area [13], containing almost all of the species present [14]. The study area was divided into 3 zones with a minimum area measured at $64 \mathrm{~m}^{2}$.

We made the statements accompanied recording stationers characters (location, altitude, exposure, substrate, geomorphology, slope and recovery rate).

This station is located near the inland basin Dayet El Ferd. We considered in our records only the presence and absence of the species, by setting the first number 1 and the second the number 0 .

Analysis of floristic surveys was made from minitab 15 software. This bio-statistical analysis led to a hierarchy of environmental factors determining the diversity of vegetation. The variables were introduced in the form of codes to facilitate the reading of factorial designs. These codes were represented by lowercase letters from the vernacular name of the taxa presented and identified from the flora Quezel \& Santa (1962) [15]. For example, it affects the species Eurucaria uncata, code (eu) (Table 3). Indices presence and absence were retained in the statistical treatment by correspondence analysis (A.F.C).

The determination of biological types of the species recorded was based on the Raunkiaer method (1934) [16].

\section{RESULTS}

\subsection{Climate}

The dry season lasts from May until October, or 6 months of drought with a drought index equal to 0.49 .

The rainfall amounts type is P.A.H.E. The value of $\mathrm{Q}_{2}$ was 18.51 .

According climagramme of Emberger, the station is positioned at the upper arid bioclimatic with cold winter (Figure 2). The bioclimatic study allowed us to deduce that the two weather variables (temperature and rainfall) contributed to the ecological bio-components, such as salinity; flooding... These factors were considered in determining the spatio-temporal distribution different plant species of halophytes.

\subsection{Soil Variables}

Texture sandy loam to loamy sand is dominant. The limestone varies between 16.3 and 23.6. An alkaline $\mathrm{pH}$ exceeding 8 at all samples.

The electrical conductivity varies from 1.2 to 14.5 $\mathrm{mS} / \mathrm{cm}$, was increasing gradually as one approaches the Daya.

The level of soluble salts in the salt-affected soils was a function of the depth of the water table salt, texture, evapotranspiration and the humidity profile [17].

Organic carbon varied between $10.2 \% 0$ and $20.6 \% 0$. The following Munsell color varied between samples (5YR5/4 5YR5/YR6 6.5/6 and 5YR4/8).

The edaphic analysis revealed some specific pre-salt steppe depressions colonized by halophyte vegetation tree on a very loose substrate texture more or less fine (silt and sand).

Other tree formations were generally excluded from this type of environment. These soils were characterized by the presence of shallow salt water and were subjected 
Table 3. Floristic inventories.

\begin{tabular}{|c|c|c|c|c|c|c|c|c|c|c|c|}
\hline SITES & & dedj & & & & & & & & & \\
\hline SLOPE & & & & & & & & & & & \\
\hline RECOVERY LEVEL & & & & & & & & & & & \\
\hline SURFACE AREA & & & & & & & & & & & \\
\hline SUBSTRATE & \multicolumn{11}{|c|}{ Lime store } \\
\hline NUMEBER OF INVENTORIES & $\mathrm{P}$ & 1 & 2 & 3 & 4 & 5 & 6 & 7 & 8 & 9 & 10 \\
\hline \multicolumn{12}{|l|}{ SPECIES } \\
\hline Stipa tenacissima & 10 & 1 & 1 & 1 & 1 & 1 & 1 & 1 & 1 & 1 & 1 \\
\hline Atractylis humilis & 5 & 1 & 0 & 1 & 1 & 0 & 0 & 1 & 1 & 0 & 0 \\
\hline Cistus villosus & 2 & 1 & 0 & 1 & 0 & 0 & 0 & 0 & 0 & 0 & 0 \\
\hline Tamarix gallica & 2 & 0 & 1 & 0 & 0 & 0 & 0 & 1 & 0 & 0 & 0 \\
\hline Helianthemum rubellum & 1 & 0 & 0 & 1 & 0 & 0 & 0 & 0 & 0 & 0 & 0 \\
\hline Thymus ciliatus & 2 & 1 & 0 & 0 & 1 & 0 & 0 & 0 & 0 & 0 & 0 \\
\hline Schismus barbatus & 8 & 0 & 1 & 1 & 0 & 1 & 1 & 1 & 1 & 1 & 1 \\
\hline Herniaria hirsuta & 8 & 0 & 1 & 1 & 1 & 0 & 1 & 1 & 1 & 1 & 1 \\
\hline Adonis dentata & 6 & 0 & 0 & 1 & 0 & 1 & 1 & 1 & 0 & 1 & 1 \\
\hline Plantago albicans & 6 & 0 & 0 & 0 & 1 & 1 & 0 & 1 & 1 & 1 & 1 \\
\hline Bromus rubens & 5 & 1 & 0 & 0 & 1 & 0 & 1 & 0 & 0 & 1 & 1 \\
\hline Poa bulbosa & 5 & 1 & 0 & 0 & 1 & 0 & 1 & 0 & 0 & 1 & 1 \\
\hline Salvia verbenaca & 5 & 0 & 1 & 0 & 0 & 0 & 1 & 1 & 1 & 0 & 1 \\
\hline Muricaria prostrata & 5 & 0 & 1 & 0 & 0 & 0 & 1 & 1 & 0 & 1 & 1 \\
\hline Koeleria phleoides & 5 & 0 & 1 & 0 & 0 & 0 & 1 & 1 & 1 & 0 & 1 \\
\hline Euphorbia falcata & 4 & 1 & 0 & 1 & 0 & 0 & 0 & 0 & 0 & 1 & 1 \\
\hline Erodium moschatum & 4 & 0 & 0 & 1 & 0 & 0 & 1 & 0 & 1 & 0 & 1 \\
\hline Ceratocephalus falcatus & 3 & 0 & 0 & 0 & 0 & 0 & 1 & 0 & 0 & 1 & 1 \\
\hline Matthiola longipetala & 3 & 0 & 0 & 0 & 0 & 0 & 1 & 0 & 0 & 1 & 1 \\
\hline Hordeum murinum & 2 & 0 & 0 & 0 & 0 & 0 & 1 & 1 & 0 & 0 & 0 \\
\hline Peganum harmala & 2 & 0 & 0 & 0 & 0 & 0 & 1 & 1 & 0 & 0 & 0 \\
\hline Sisymbrium runcinatum & 1 & 1 & 0 & 0 & 0 & 0 & 0 & 0 & 0 & 0 & 0 \\
\hline Koeleria pubescens & 1 & 1 & 0 & 0 & 0 & 0 & 0 & 0 & 0 & 0 & 0 \\
\hline Eruca vesicaria & 1 & 1 & 0 & 0 & 0 & 0 & 0 & 0 & 0 & 0 & 0 \\
\hline Aegilops triuncialis & 1 & 0 & 1 & 0 & 0 & 0 & 0 & 0 & 0 & 0 & 0 \\
\hline Marrubium vulgare & 1 & 0 & 0 & 0 & 0 & 1 & 0 & 0 & 0 & 0 & 0 \\
\hline Paronychia argentea & 1 & 0 & 0 & 0 & 0 & 0 & 1 & 0 & 0 & 0 & 0 \\
\hline Micropus bombycinus & 7 & 1 & 1 & 1 & 1 & 0 & 0 & 1 & 1 & 0 & 1 \\
\hline Alyssum campestre & 6 & 0 & 0 & 1 & 1 & 0 & 1 & 1 & 0 & 1 & 1 \\
\hline Astragalus epiglottis & 5 & 0 & 0 & 1 & 0 & 0 & 1 & 0 & 1 & 0 & 1 \\
\hline Brachypodium distachyum & 4 & 0 & 0 & 0 & 0 & 0 & 1 & 1 & 1 & 0 & 1 \\
\hline Trigonella polycerata & 3 & 0 & 0 & 0 & 1 & 1 & 0 & 0 & 0 & 1 & 0 \\
\hline Echinaria capitata & 3 & 0 & 0 & 0 & 0 & 0 & 1 & 0 & 0 & 1 & 1 \\
\hline Medicago truncatula & 2 & 1 & 1 & 0 & 0 & 0 & 0 & 0 & 0 & 0 & 0 \\
\hline Astragalus pentaglottis & 2 & 0 & 0 & 0 & 0 & 0 & 0 & 0 & 0 & 1 & 1 \\
\hline Teucrium pseudo-chamaepitys & 1 & 1 & 0 & 0 & 0 & 0 & 0 & 0 & 0 & 0 & 0 \\
\hline Bupleurum semi-compositum & 1 & 0 & 0 & 1 & 0 & 0 & 0 & 0 & 0 & 0 & 0 \\
\hline Euphorbia exigua & 1 & 0 & 0 & 0 & 0 & 1 & 0 & 0 & 0 & 0 & 0 \\
\hline Evax pigmaea & 1 & 0 & 0 & 0 & 0 & 0 & 0 & 0 & 0 & 0 & 1 \\
\hline Medicago minima & 7 & 0 & 1 & 1 & 1 & 1 & 0 & 1 & 1 & 1 & 0 \\
\hline Malva aegyptiaca & 7 & 0 & 1 & 0 & 1 & 0 & 1 & 1 & 1 & 1 & 1 \\
\hline Noaea mucronata & 5 & 0 & 1 & 0 & 0 & 0 & 1 & 1 & 1 & 1 & 0 \\
\hline
\end{tabular}




\begin{tabular}{|c|c|c|c|c|c|c|c|c|c|c|c|}
\hline Filago spathulata & 5 & 0 & 0 & 0 & 1 & 1 & 0 & 1 & 0 & 1 & 1 \\
\hline Atractylis serratuloides & 2 & 1 & 1 & 0 & 0 & 0 & 0 & 0 & 0 & 0 & 0 \\
\hline Echium pycnanthum & 2 & 0 & 1 & 0 & 1 & 0 & 0 & 0 & 0 & 0 & 0 \\
\hline Scorzonera undulata & 1 & 1 & 0 & 0 & 0 & 0 & 0 & 0 & 0 & 0 & 0 \\
\hline Helianthemum apertum & 1 & 1 & 0 & 0 & 0 & 0 & 0 & 0 & 0 & 0 & 0 \\
\hline Helianthemum hirtum & 1 & 1 & 0 & 0 & 0 & 0 & 0 & 0 & 0 & 0 & 0 \\
\hline Launea residifolia & 1 & 0 & 1 & 0 & 0 & 0 & 0 & 0 & 0 & 0 & 0 \\
\hline Salsola vermiculata & 1 & 0 & 0 & 1 & 0 & 0 & 0 & 0 & 0 & 0 & 0 \\
\hline Sanguisorba minor & 1 & 0 & 0 & 0 & 0 & 0 & 0 & 0 & 1 & 0 & 0 \\
\hline
\end{tabular}

P: Presence.

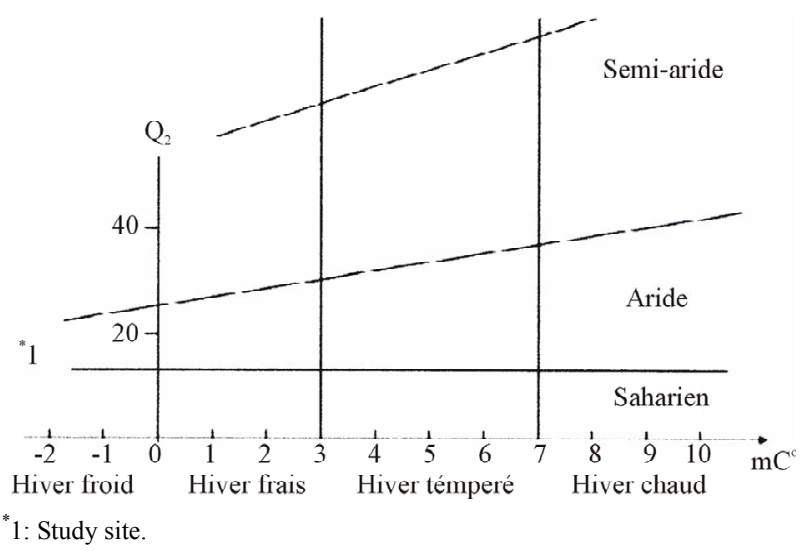

Figure 2. Positioning of the study area on the Emberger climagramme.

since their implementation in terms of salinity and large water logging with variable intensity [18].

\subsection{Discrimination by Correspondence Analysis (A.F.C)}

The A.F.C has allowed us to individualize sets of species with similar ecological affinities; it clarifies the structures of differentiated vegetation in these stands [19]. Therefore, it can highlight the strong cash contribution in factorial designs and understand the distribution of these. This distribution is undeniably dependent on environmental factors.

Floristic surveys at this station show the presence of a population dominated by halophyte species Tamarix gallica L. introduced into the area by reforestation in the 1970 around the periphery of the Daya. This taxon is reproduced perfectly alongside therophytes species (Brachypodium distachyum, Micropus bombicinus...).

The minitab 15 software processes sets of species were distributed along the factorial designs formed by the Axes (1 and 2) with strong contributions. We tried to understand the distribution function of gathering structures of vegetation governed by environmental factors identified by gradients whose meaning obeys the location of the cash contribution of strong factorial designs [20].

Each species represented by a code took its place on factorial designs.

The rest of the taxa included in the (Table 4) which are represented, their contact with the values on Axis 1 and 2 . These values allowed us to easily identify the species of the factorial design.

\section{Interpretation of Factorial Designs}

- (Zone 1). Axis 1 - 2 (Figure 3). Value = 4.73. Inertia ratio $=47 \%$. This axis contains in the positive side species indicator gradients of salinization Tamarix gallica (2.0) of psammophitisation Schismus barbatus (1.9) and overgrazing Noaea mucronata (0.9). Tese gradients replaced limestone gradient indicated by the species Poa bulbosa (0.3). We also found some post-crop species Malva aegyptiaca (1.7) and Muricaria prostrata (1.0)...

On the negative side position, we found steppe species of Mediterranean dry grasslands, Thymus ciliatus ( -0.9$)$ and Koeleria pubescens $(-1.2) \ldots$ The gradients presented are those that show the human impact and therophitisation Astragalus pentaglottis $(-0,1)$ and Marrubium vulgare $(-0.7) \ldots$

- (Zone 2). Axis 1 - 2 (Figure 4). Value $=4.63$. Inertia ratio $=46 \%$.

At this axis we find halophytes taxa Tamarix gallica (0.2), Brachypodium distachyum (0.6) creating a positive and increasing salinity gradient.

The gradient was also represented by psammophitisation, Schismus barbatus (0.4) alongside other gradients like overgrazing and steppe, Noaea mucronata (1.2), Micropus bombycinus (1.8).

On the negative side appeared species of the steppes and dry pre-steppes, like Adonis dentata $(-1.4)$ Filago spathulata (-1.8), Astragalus Pentaglottis (-1.4) generating gradients steppe and human impact.

- (Zone 3). Axis 1 - 2 (Figure 5). Value = 2.70. Inertia ratio $=27 \%$.

This line seemed to be managed by the same environmental factors that these precedents. 
Table 4. Coordinates of species.

\begin{tabular}{|c|c|c|c|c|}
\hline SPIECES & Code & Indiv. & Axis: 1 & Axis: 2 \\
\hline Tamarix gallica & $\operatorname{tg}$ & 1 & 2.06176483 & 1.82268615 \\
\hline Atractylis humilis & $\mathrm{ahu}$ & 2 & 0.18746175 & 1.94189319 \\
\hline Cistus villosus & $\operatorname{civ}$ & 3 & -1.03007347 & 0.82624634 \\
\hline Helianthemum rubellum & hru & 3 & -0.78923077 & 0.09870069 \\
\hline Thymus ciliatus & tc & 3 & -0.9316649 & 1.32637496 \\
\hline Schismus barbatus & $\mathrm{sb}$ & 4 & 1.96419167 & 0.09521696 \\
\hline Herniaria hirsuta & hh & 5 & 1.98563516 & 0.18977741 \\
\hline Adonis dentata & ade & 6 & 1.30057226 & -0.05221344 \\
\hline Plantago albicans & pa & 7 & 1.37906351 & 1.32570799 \\
\hline Bromus rubens & br & 7 & 0.33587037 & 0.18333438 \\
\hline Poa bulbosa & $\mathrm{pb}$ & 7 & 0.33587037 & 0.18333438 \\
\hline Salvia verbenaca & sav & 7 & 0.97244641 & -1.40852751 \\
\hline Muricaria prostrata & $\mathrm{mp}$ & 7 & 1.03338802 & -1.33890099 \\
\hline Koeleria phleoides & $\mathrm{kph}$ & 7 & 0.97244641 & -1.40852751 \\
\hline Euphorbia falcata & ef & 7 & -0.1562795 & 0.53203863 \\
\hline Erodium moschatum & emo & 7 & 0.4173629 & -1.11396642 \\
\hline Ceratocephalus falcatus & $\mathrm{cf}$ & 7 & 0.23829721 & -1.54413482 \\
\hline Matthiola longipetala & $\mathrm{ml}$ & 7 & 0.23829721 & -1.54413482 \\
\hline Hordeum murinum & $\mathrm{hm}$ & 7 & -0.13020138 & -1.16316374 \\
\hline Peganum harmala & $\mathrm{ph}$ & 7 & -0.13020138 & -1.16316374 \\
\hline Sisymbrium runcinatum & $\mathrm{sr}$ & 3 & -1.27008077 & 0.32645142 \\
\hline Koeleria pubescens & $\mathrm{kp}$ & 3 & -1.27008077 & 0.32645142 \\
\hline Eruca vesicaria & eve & 3 & -1.27008077 & 0.32645142 \\
\hline Aegilops triuncialis & at & 3 & -0.73944263 & -0.28262378 \\
\hline Marrubium vulgare & $\mathrm{mv}$ & 7 & -0.71226568 & 0.50426885 \\
\hline Paronychia argentea & pa & 7 & -0.63549676 & -1.24992711 \\
\hline Micropus bombycinus & $\mathrm{mb}$ & 2 & 0.91628556 & 1.66756947 \\
\hline Alyssum campestre & alc & 6 & 1.32201575 & 0.04234701 \\
\hline Astragalus epiglottis & ae & 7 & 0.4173629 & -1.11396642 \\
\hline Brachypodium distachyum & bd & 7 & 0.68265098 & -1.52699798 \\
\hline Trigonella polycerata & tp & 7 & 0.06091577 & 1.60277886 \\
\hline Echinaria capitata & ec & 7 & 0.23829721 & -1.54413482 \\
\hline Medicago truncatula & $\mathrm{mt}$ & 3 & -0.98028533 & 0.44492188 \\
\hline Astragalus pentaglottis & ap & 7 & -0.15544409 & -0.69530195 \\
\hline Teucrium pseudo-chamaepitys & tpc & 3 & -1.27008077 & 0.32645142 \\
\hline Bupleurum semi-compositum & bsc & 3 & -0.78923077 & 0.09870069 \\
\hline Euphorbia exigua & ee & 7 & -0.71226568 & 0.50426885 \\
\hline Evax pigmaea & ep & 7 & -0.59020968 & -0.79388841 \\
\hline Medicago minima & $\mathrm{mm}$ & 8 & 1.46983785 & 2.33676754 \\
\hline Malva aegyptiaca & $\mathrm{ma}$ & 5 & 1.74562787 & -0.31001751 \\
\hline Noaea mucronata & $\mathrm{nm}$ & 7 & 0.96818362 & -0.91714688 \\
\hline Filago spathulata & fs & 7 & 1.00523953 & 1.29674805 \\
\hline Atractylis serratuloides & ats & 3 & -0.98028533 & 0.44492188 \\
\hline Echium pycnanthum & ep & 3 & -0.40102676 & 0.71729977 \\
\hline
\end{tabular}




\section{Continued}

\begin{tabular}{ccccc}
\hline Scorzonera undulata & su & 3 & -1.27008077 & 0.32645142 \\
Helianthemum apertum & hap & 3 & -1.27008077 & 0.32645142 \\
Helianthemum hirtum & hhi & 3 & -1.27008077 & 0.32645142 \\
Launea residifolia & Lr & 3 & -0.73944263 & -0.28262378 \\
Salsola vermiculata & $\mathrm{sv}$ & 3 & -0.78923077 & 0.09870069 \\
Sanguisorba minor & $\mathrm{sm}$ & 7 & -0.65541408 & -0.3721343 \\
Stipa tenacissima & $\mathrm{stt}$ & 7 & -0.65541408 & -0.3721343 \\
Artemisia herba-alba & aha & 7 & -0.65541408 & -0.3721343 \\
\hline
\end{tabular}

Indiv.: Individuel.

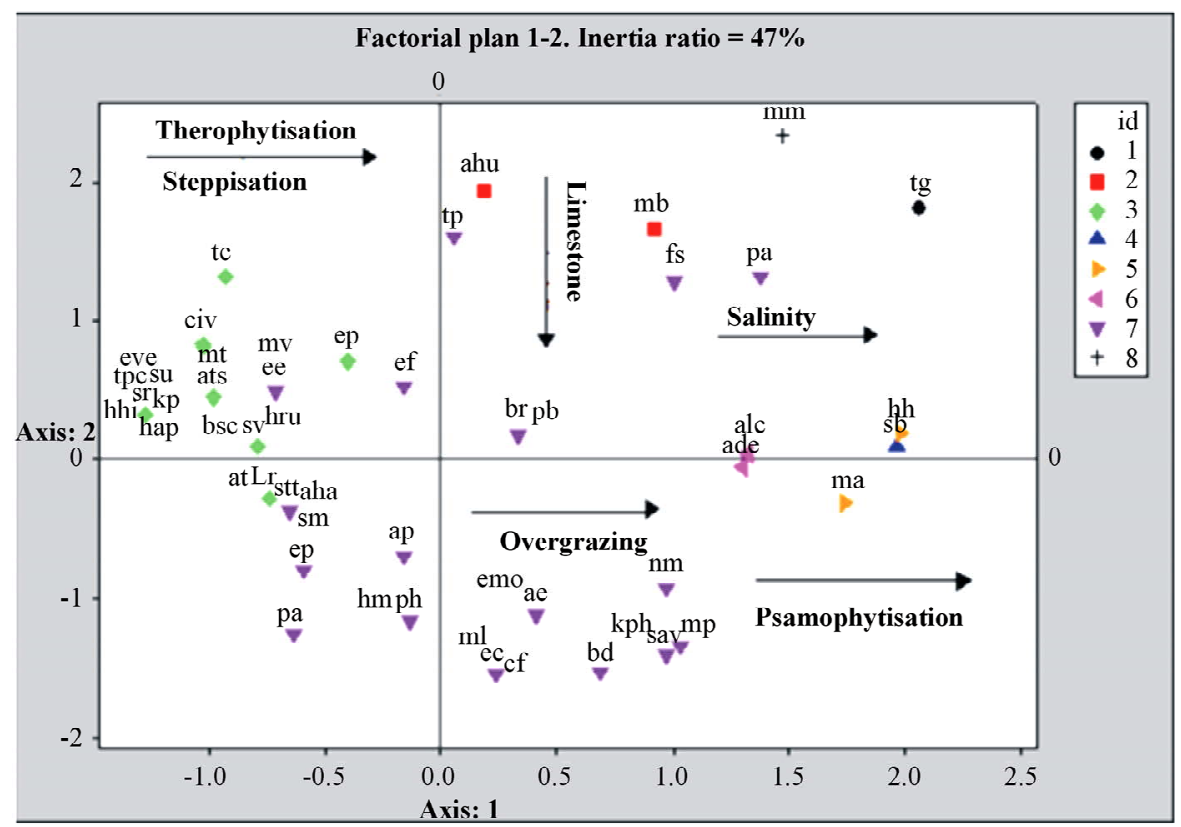

Figure 3. Factorial plan of taxa: Axis 1 - 2 (Zone 1).

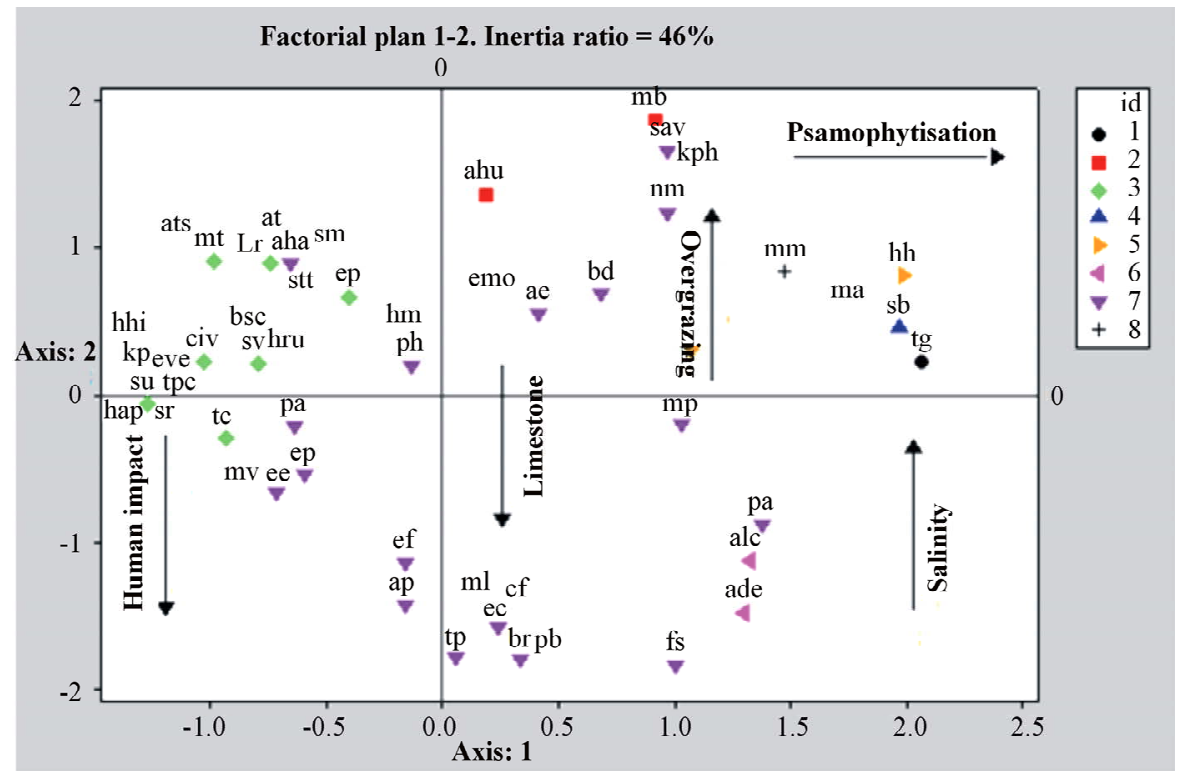

Figure 4. Factorial plan of taxa: Axis 1 - 2 (Zone 2). 


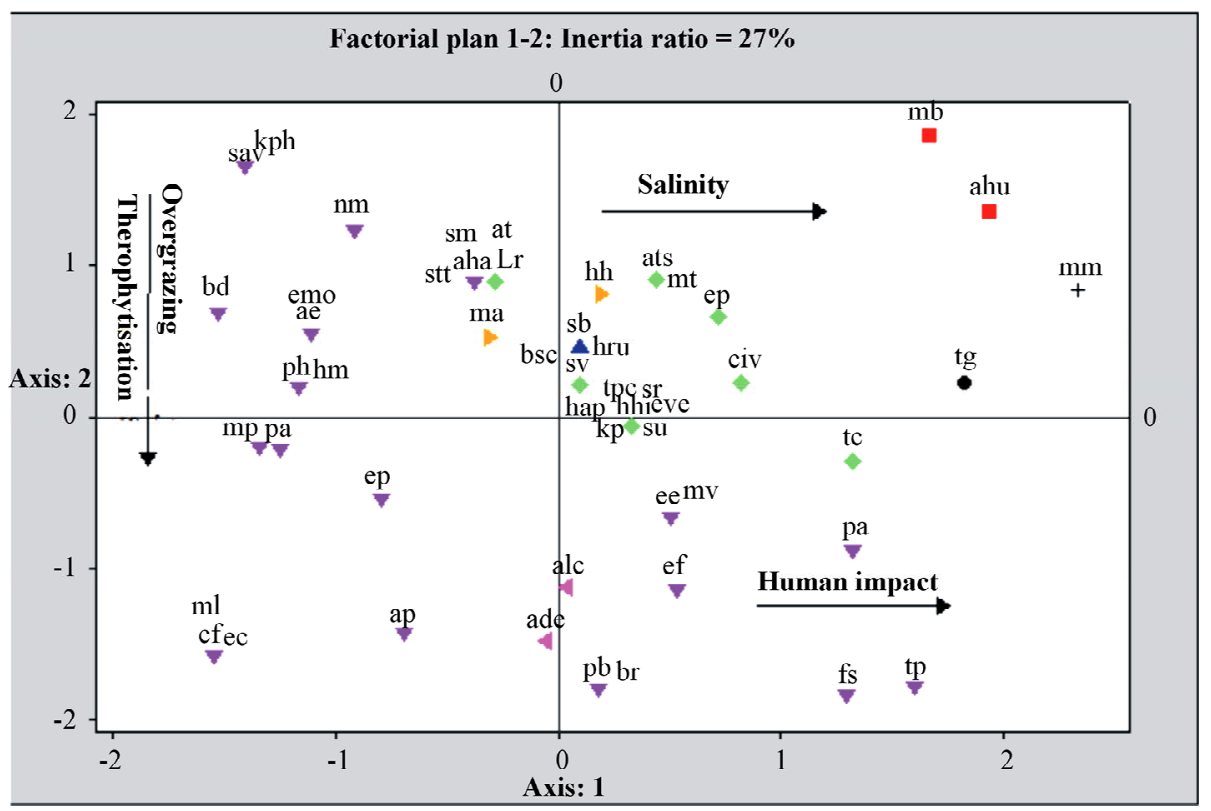

Figure 5. Factorial plan of taxa: Axis 1 - 2 (Zone 3).

\subsection{Floristic Diversity (Figure 6)}

Many examples show that changes in the composition and reduced diversity exert some influence on the biological characterization and especially the distribution of different classes of biological and morphological types and the systematic and biogeographical distribution.

\subsubsection{Biological Types}

The floristic composition contains $41 \%$ of therophytes, $38 \%$ of chamaephytes, $9 \%$ of hemicryptophytes and $6 \%$ of geophytes and phanerophytes. It seems again that the plant communities identified also give great importance to therophytes and chamaephytes.

These two types of vegetation are well adapted to steppe zones. Overgrazing and aridity have consistently led the development of taxa such as, Noaea mucronata, Atractylis serratuloides, Peganum harmala...

\subsubsection{Morphological Types}

Woody perennials types took the first dominant position with a rate of $37 \%$ followed by perennials herbaceous with $34 \%$ and annual herbs with $29 \%$.

\subsubsection{Systematically Characterization}

This area is characterized by the dominance of taxa belonging to the botanical family of Chenopodiaceaes $(25 \%)$. This category consists mainly of halophytes subjects.

The Asteraceaes and Poaceaes occupy second and third place with rates of $21 \%$ and $12 \%$ respectively. The rest is accounted for by families whose rate does not exceed $5 \%$.

\subsubsection{Biogeography Characterization}

The strict Mediterranean element and circum-Méditerraneen occupy the first place with $30 \%$, followed by the cosmopolitan species with $13 \%$. The rest goes to the Sahara element with a rate that does not exceed $7 \%$.

\section{DISCUSSION}

In this work, bioclimatic study area clearly indicates that we are in arid zone, which is a reduction factor of the floristic diversity that allows the installation of salttolerant vegetation. This halophytic vegetation has developed around the inland basin of the Daya creating a humid microclimate in dry areas [21]. At this scale, bioclimatic asymmetry creates fairness in the distribution of vegetation will depend on orographic and topographic contrasts.

On the substrate, the predominance of fine texture gives it a sandy-loam texture. The fine silts and clays react primarily to the dynamics of salts [22]. Indeed during the dry season, they favor the ascending soluble salts by capillary rise and salinity gradient is then directed towards the surface movement. In the rainy season, they promote stagnation of water and water logging of superficial horizon. Both soil factors (salinity and texture) are fundamentally responsible for the distribution of salttolerant species in our area.

The dynamic schemes developed from the factorial plans have managed to highlight ecological gradients of human impact (overgrazing and degradation) and biological gradients (therophytisation and psamophitisation). This link leads to a tendency to contiguity wealth therophytes which seems to be a corollary to the degradation 

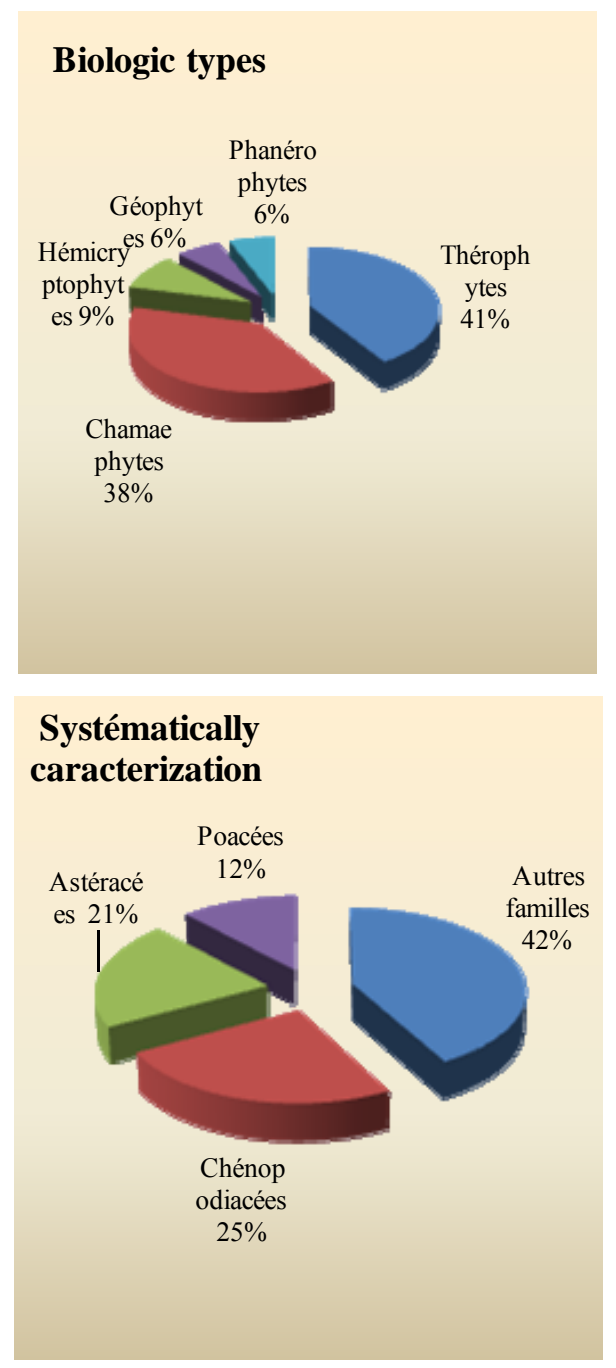

Figure 6. Representation areas of biological forms.

and desertification. We are in front of an adaptation strategy to lower canopy and soil resources. In any case, the rate of therophytes in plant communities naturally increases with aridity [23].

\section{CONCLUSIONS}

Algerian steppe was exposed for a long time to intensive exploitation of these resources (uprooting, grazing...). It is in the process of losing its potential resilience that ensured its restoration by a simple rational management. A state of floristic and ecological places could be very beneficial any time to initiate conservation programs.

The study of the vegetation in the steppe ecosystem sparked a demonstration of a number of gradients that are managed by different environmental factors. These gradients were positive or negative with respect to the center axes. The origin of these factors has a link with soil (salinity, lime...), human impact (overgrazing, deg-

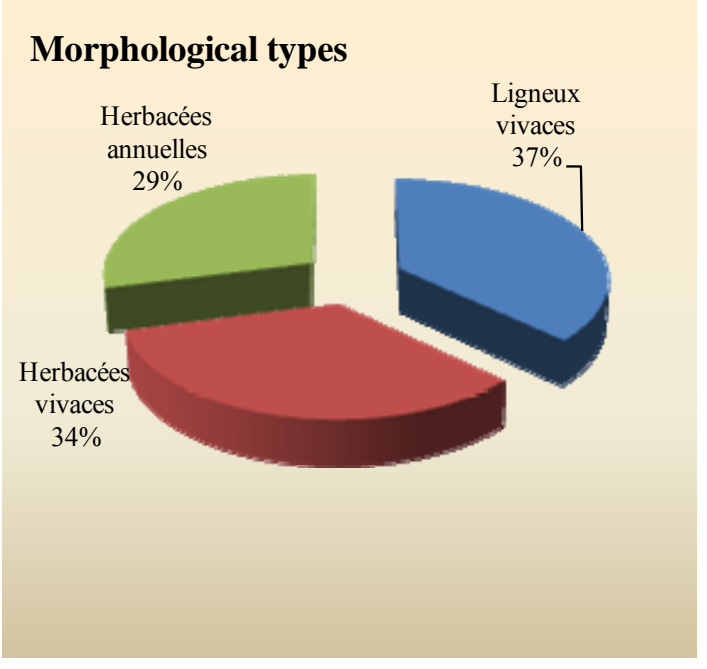

Biogeography caracterisation

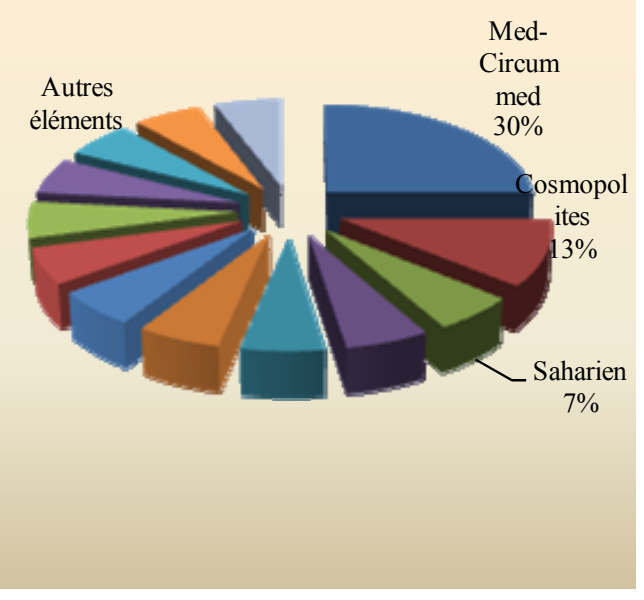

radation) and biological (therophytisation, psamophitisation).

The plant communities of this area are dominated by chamaephytes and characterized by a low representation of hemicryptophytes and geophytes. On the phytochorique map the Mediterranean element (30\%) dominates the other.

As for biodiversity beyond the local extinction of many species of pastoral taxa considered like "macro species", and lost their most important representation in terms of productive potential. Under the weight of permanent grazing, their gene pool is heavily eroded. This calls for further study of some endemic taxa to assess if possible the state of their regression.

The identification of these ecological gradients could be used to reorganize the research areas in these ecosystems. A triggering of a global approach will be based on a participatory conservation management device [24].

Finally, the recommendation for the preservation of 
these populations in vulnerable areas could save a threatened biodiversity, and make sure even the breeding of livestock in the pastoral areas [25].

\section{REFERENCES}

[1] Higazy, M.A., Shehata, M. and Allam, A. (1995) Free proline relation to salinity tolerance of three sugar beet varieties. Egypt. Journal of Agriculture, 73, 175-189.

[2] Lauchli, L. and Epstein, E. (1990) Plant response to saline conditions. Agricultural Salinity Assensmentand Management, 15, 113-137.

[3] Tremblin, G. (2000) Comportement auto-écologique de Halopeplis amplexicaulis plante pionnière des Sebkha de l'Ouest algérien. Rev Sech. 11, 109-116.

[4] Ozenda, P. (1991) Flore et végétation du sahara. C.N.R.S. 3rd Edition, T.III, Paris, 660 p.

[5] Le Houerou, H.N. (2000) Use of fodder trees and shrubs (trubs) in the arid and semi-arid zones of west Asia and North Africa. Proceeding of Workshop on Native and Exotic fodder Shrubs in arid and Semi-arid Zones, 1, 9-53.

[6] Zohary, D. (1974) Domestication of pulses in the old world. Rev Scien, 182, 887-994.

[7] Viano, J. (1963) Etude phytosociologie et écologique de la région de Fès. Univ. Marseille III. Thèse 3ème Cycle Ecologie, $122 \mathrm{p}$.

[8] Babinot, M. (1982) Promotoire oriental du grand Rhône (embouchure). Etude de la végétation et cartographie écologique des aires culicidogènes à Aedes. Caspius en milieu instable. Thèse Doct. Sci. St Jérôme, Aix-Marseille III.

[9] Le Houerou, H.N. (1993) Land degradation in méditerranean Europe: Can agroforestery be a part of the solution? Agroforestry Systems, 21, 43-61.

[10] Lemee, G. (1978) Précis d'écologie végétale. Masson et Cie, Paris.

[11] Braun Blanquet, J. (1951) PF Lauzensoziologie, Grundzuge, Vegetations Kunde Ed. 2 Springer, Vienne Autriche, $631 \mathrm{p}$.

[12] Guinochet, M. (1973) Phytosociologie. Masson et Cie, Paris, $177 \mathrm{p}$.

[13] Godron, M., Daget, P.H. and Emberger, L. (1983) Code pour le relevé méthodique de la végétation et du milieu. C.N.R.S., Paris, 296 p.

[14] Chaabane, A. (1993) Etude de la végétation du littoral septentrional de la Tunisie: Typologie: Syntaxonomie et éléments d'aménagement. Thèse Doct Es-Sci, Univ-AixMarseille III. Fac-Sci et Tech. $\mathrm{S}^{\mathrm{t}}$ Jerome, $216 \mathrm{p}$.

[15] Quezel, P. and Santa, S. (1962) Nouvelle flore de l'Algérie et des régions méridionales CNRS. Tome 1 et 2, 1190 p.

[16] Raunkiaer, C. (1934) The life form of plants and statistical plant geography. Clarendon Press, Oxford.

[17] Bendaanoun, M. (1981) Etude synécologique et dynamique de la végétation halophile et hydro-halophile et de l'estuaire de Bou-Reg-Reg (Atlantique du Maroc). Application et perspectives d'aménagement. Thèse Doct. Ing Univ. St Jérome, Aix-Marseille III, 221 p.

[18] Hanotiaux, G., Lancla, C. and Mathieu, L. (1976) Un exemple d'évaluation des sols salins suite à la mise en valeur par la rizière en Camargue. Ann. Inst. Nat. Agron. ELHarrach, 6, 259-318.

[19] Aboura, R., Benmansour, D. and Benabadji, N. (2006) Comparaison phytoecologique des Atriplexaies en Oranie (Algérie). Ecol Med, 32, 73-84.

[20] El-Hamrouni, A. (1992) Végétation forestière et préforestière de la Tunisie. Typologie et éléments pour la gestion. Thèse Doct-état, Univ. Marseille, 220 p.

[21] Aidoud, A., Le Floc'h, E. and Le Houerou, H.N. (2006) Les steppes arides du nord de l'Afrique. Rev Sech, 17, 19-30.

[22] Benabadji, N., Bouazza, M., Metge, G. and Loisel, R. (1996) Description et aspect des sols en régions semiarides et arides au sud de Sebdou (Oranie, Algérie). Bull Inst Sci, 20, 77-86.

[23] Maire, R. (1962) Contribution à l'étude de la flore de l'Afrique du Nord. Bull Soc Afr Nord, 26, 186-196.

[24] Nedjraoui D., Hirche, A. and Boughani, A.F. (1999) Désertification par télédétection des hautes plaines steppiques du Sud-Ouest oranais. U.R.B.T. et I.N.C. Alger, 17, 10-22.

[25] Mostefa, S.A. and Benariad, M. (1999) Suivi diachronique des processus de désertification in situ et par télédétection des hautes plaines steppiques du Sud-Ouest oranais. U.R.B.T. et I.N.C. Alger, 16, 9-15. 